Social Sciences, Humanities and Education Journal (SHE Journal)

Volume 1 (3) 53 - 57, September 2020 | ISSN: 2720-9946 (Online) | ISSN: 2723-3626 (Print)

The article is published with Open Access at: http://e-journal.unipma.ac.id/index.php/SHE

\title{
THE NOTHINGNESS OF THE GETTIER PROBLEM
}

Tom Eneji Ogar $\bowtie$, Department of Philosophy, University of Calabar, Calabar, Cross River State, Nigeria.

Edor J. Edor, Department of Philosophy, University of Calabar, Calabar, Cross River State, Nigeria.

\begin{abstract}
This work, "The Nothingness" of the Gettier Problem is an attempt to deconstruct the popularly held view that a fourth condition may be necessary for the Traditional Account of Knowledge otherwise known as JTB. Plato, it was who championed the traditional account of knowledge as justified Belief in response to the agitation of the skeptics notably Georgias and Protagoras. This tripartite account held sway until Edmund Gettier Challenged the position with his article "Is Jus tified True Belief Knowledge?" Since this challenge, scholars have tried to s olve what has become known as the Gettier Problem by trying to fashion out a fourth condition to JTB. This work argues that the celebrated Gettier counter -examples in the challenge of the tripartite account is a "nothingness". The traditional account is ra ther fundamental in knowledge claim, hence any new vista in form of additional information on JTB should not invalidate it. The textual analysis was adopted as a method for this research.
\end{abstract}

Keywords Edmund Gettier, Truth, Classical Logic, Gettier Problem.

$\bowtie$ enejiogar93@gmail.com

Citation: Ogar, T. E. \& Edor, J. E. (2020). The nothingness of the gettier problem . Social Sciences, Humanities and Education Journal (SHE Journal), 1(3), 53 - 57. DOI: 10.25273/she.v1i3.7553

\section{$(\mathrm{Cc}) \mathrm{BY}-\mathrm{NC}-\mathrm{SA}$}

Published by Universitas PGRI Madiun. This work is licensed under the Creative Commons Attribution NonCommercialShareAlike 4.0 International License. 


\section{INTRODUCTION}

The question of the impossibility of knowledge was sparked by the skeptics in their attack on the nature and justification of claims to knowledge. Over the periods in philosophy, scholars have in various ways tried to find avenues to make the foundations for knowledge claims firm noting that if the skeptic doubt is allowed to hold sway, it will undermine the total foundation of knowledge. In doing this, philosophers have embarked upon the analysis of what constitutes knowledge by trying to identify the basic criteria for knowledge claim. It is not out of place therefore to conclude that skepticism was the background for the search for necessary conditions of knowledge. A notable skeptic of antiquity was Gorgias who took the skeptical attitude to an extreme. His position is different from that of Protagoras in that while the truth is relative to the individual and the circumstances, for Gorgias there is nothing like truth at all (Pratt 2015). For Gorgias, human beings communicate with words, but these words are mere symbols, and that there can be no on-onone correspondence between words and what they represent. In this regard, knowledge can neither be achieved nor can it be communicated (Stumph 2002, pp. 33).

As seen above, the different opinions held by the skeptics led to many different ethical and political standards. At this point, Plato in a bid to produce incorruptible citizens for the state of Athens developed a theory of knowledge that was to counter skepticism and moral relativism. Here, it is reasoned that a proper analysis of the nature of justification of our knowledge claims would be a pre-condition for the articulation of other philosophical claims.

Plato's analysis is trying to provide a foundation and criterion for knowledge to counter the skeptics explains that if a belief is true and can be justified, it automatically qualifies to be referred to as knowledge. This approach gave impetus to what has become known as JTB (Justifiable True Belief). This is the traditional account of knowledge and became accepted generally by most philosophers and scholars in the field of Epistemology. As accepted by philosophers, this traditional definition was challenged by Gettier in a three-page article, "Is Justified True-Belief Knowledge" in 1963. Arguing that JTB is inadequate for knowledge, Gettier was of the view that one could have a justified true belief and yet does not have knowledge. Several reactions both for and against have trailed this position, leading to the Gettier problem in philosophy (Demin 2019).

With the Gettier challenge, scholars have reasoned the need for the fourth condition to JTB, but this paper submits that Gettier has rather brought in skepticism in another form hence any new twist to JTB enriches rather than destroys it.

\section{THE TRADITIONAL ACCOUNT OF KNOWLEDGE}

As noted earlier, what is today known as the traditional account (JTB) was an attempt to respond to the skeptical challenge on the possibility of knowledge. As a result of the fact that the account goes by three parts, it is sometimes referred to as the "tripartite" definition or the tripartite account (Dancy: 1981, pp. 23). This account holds that three core conditions must be fulfilled for any claim to be considered as knowledge. These conditions were brought up in the THEATUS, one of Plato's dialogues, where his description of knowledge entails that knowledge is justified true belief. In this regard, Plato submits;

Where anyone forms the true opinion of anything without rational explanation, you may say that his mind is truly exercised, but has no knowledge for he who cannot give and receive a reason for a thing has no knowledge of that 
thing, but he who adds the rational explanation, then he is perfect in knowledge... True opinion combined with definition or rational explanation, is knowledge (1990, pp. 545)

From the analysis, as shown above, Plato aptly made a distinction between an option and true knowledge as the latter is followed with some rational explanation. It is this rational angle to an opinion that epistemologists refer to as justification.

In support of the foregoing analysis, Hetherington has this to posit; "a true belief is not knowing if it is the result of guesswork. To be knowledge, it must be justified by, for example, appropriate evidence (2005, pp. 21). The trust of the traditional account of knowledge is that propositional knowledge constitutes three basic conditions. To this end, it can only be concluded that $\mathrm{Mr}$. $\mathrm{X}$ knows a proposition $\mathrm{P}$, if and only if;

a. $P$ is true

b. $X$ believes that $P$ is true

c. $\mathrm{X}$ is justified in believing that $\mathrm{P}$ is true

The implication here is that knowledge requires not only that our beliefs be true, but also that we have a good rational explanation to be justified in believing them to be true. Thus knowledge is justified true belief according to the traditional account. The three features are therefore not only necessary but are sufficient conditions for knowledge. The traditional account of knowledge held sway and enjoyed popular appeal until it was challenged by Gettier in his work, "Is Justified True Belief Knowledge?"

\section{THE GETTIER EPISTEMOLOGICAL QUAGMIRE}

In his highly influential paper, "Is justified true belief knowledge?", Gettier presents two thought experiments otherwise known as counter-examples to suggest that there was a fundamental problem with the traditional account of knowledge which was brought forward by Plato to counter the skeptics. These thought experiments seem to show that JTB was inadequate for knowledge by proving that someone could have a justified true belief and also lack knowledge.

Because the Gettier counter-examples share the same logical construct and structure, it is expedient to consider only one of the thought experiments here, in this case, "Gettier's job seekers", For Gettier,

Suppose that two people, Smith and Jones have applied for a job. Suppose that Smith has a justified belief that Jones will get the job. The evidence for it is high enough that Smith justifiably beliefs it, might be that the president of the company assured him that Jones would in the end be selected (1963, pp. 121).

In furtherance of this narrative; Smith also believes (and indeed knows that Jones has ten coins in his pocket, which is true and is demonstrated to him, possibly by Jones counting them himself. From this, he believes the logical consequence of these beliefs, that the man who will get the job has ten coins in his pocket.

Gettier brings his thought experiment to the crucial point when he implores us to suppose further that;

It turns out that Smith was wrong, and that, for some unforeseeable reason, it turns out that Smith gets the job, and Jones does not. It also turns out that Smith has ten coins in his pocket, though he didn't realize it. The question is, was Smith's belief that, the man who will get the job has ten coins in his pocket knowledge?

Gettier counter-examples essentially follow the same structure;
a. Smith justifiably believes that $P$
b. $\mathrm{P}$ is false
c. Smith correctly infers that if $\mathrm{P}$ is true, then $Q$ is true
d. So Smith believes that $Q$, justifiably
e. $Q$ is true, but not because of $P$ 
f. So, Smith has a justified true belief that $\mathrm{Q}$

The flaws arise from forming an inference based on a false premise, though there is sufficient evidence to believe that premise is true.

The Gettier counter-example as enunciated shows that, Smith had a justified true belief, yet does not know. This is the case because his knowledge was a mere coincidence as he arrived at a true proposition based on facts that were not relevant to the truth of the proposition (Schick \& Vaughan: 1999, pp. 430).

From the foregoing, it is not out of place to draw a line out of the thought experiments to the extent that any knowledge claim should not be based on guesswork and coincidence, but rather on a guarantee of sufficient evidence. This is to the extent to which the Gettier counter-examples can go. From the analysis -made so far, scholars and philosophers have since Gettier published his famous but contentious 1963 article, tried to think out of the box towards the addition of the fourth condition to JTB, redefine to do away with the independence of the conditions or a claim that they do not meet the justification requirement. However, the popular acclaim has been to modify the JTB to reach a capable "Gettier-proof" epistemic theory of knowledge (Abbasian 2012, pp. 108). The quest to address the challenge posed by the counter-examples of Edmund Gettier in his article has been variously referred to as "The post Gettier analysis of knowledge or the search for the fourth condition of knowledge.

\section{THE GETTIER PROBLEM: “A NOTHINGNESS"}

As have been pointed out from the previous analysis, the Traditional Account of Knowledge also known as the Tripartite account was called to question by Edmund Gettier. With this X-ray, Gettier was to open a new frontier in the domain of Epistemology. The defect identified in the tripartite account of knowledge has since become known as "The Gettier problem".

A major outlook of philosophical enterprise is the fact that, the answers provided by any particular philosopher is not usually seen as what is fundamental, but that the questions and answers are attempted at all. In this regard, the various attempts by scholars to address the Gettier problem have had their own defects. Going forward, therefore, it is the position of this paper that, the significance of the counter-examples is limited, leading to a misunderstanding of the JTB definition, hence the Gettier problem is a "nothingness". In fact, as used by Jean-Paul Sarte, "nothingness" plays an important role in shaping who we are and what we can know (Depestre 2007).

It is a known fact that every time we make a choice we have to envisage that which does not yet exist. In other words, I have to imagine that I am now the professor of what I contemplate to purchase. What I am thinking about at the moment is not what already exists but what has been and is no more (the past) and what I might bring about by my daily choices (the future). Both of these scenarios have the character of "nothingness".

In everything we do, we look to nothing. I am hungry - I intend something which does not at present exist; my eating a meal. I think of the next word to type on the keyboard, at the moment of thinking it, it does not yet exist. We are always aiming at that which we are not, at the nothing which is future, while influenced by our own personal history, the "nothing" which is past (Rodgers \& Thompson 2011, pp. 38).

At any one moment, human beings can turn their attention from what is to what might likely be. Here we are concerned with that which does not at this present moment exist, that is a 
"nothingness" that surrounds the present existing moment.

The same scenario painted above is equally true of knowledge acquisition. The knowledge that one had in the past is knowledge as that goes, hence additional information in that regard is an added advantage and should not diminish the tripartite account of knowledge. Knowledge requires JTB fundamentally but any future input of additional evidence should not defeat the knowledge justification. Knowledge exists as justified true belief is always waiting to be filled by the daily activities of man.

\section{CONCLUSION}

It is obvious from the narrative done so far that the search for an appropriate characterization of the nature of knowledge is quite a task. This quest has engaged philosophers' attention from time beginning with Plato's tripartite account of knowledge to the present. As indicated in this work, the JTB account of knowledge is fundamental in our definition of knowledge hence the famous Gettier problem is a "nothingness". The conditions for "Justified True Belief" recognize the major concerns of epistemologists in their claim to knowledge. In this regard, it is a given that the quest for an indubitable knowledge is an everevolving one, a "nothingness" waiting to be always filled by man's daily activities and choices. At any time new vistas are added, to any knowledge claim, it should not defeat JTB.

\section{REFERENCES}

Abbasian, M. A. (2012). What's Wrong with Irrefutability and Defeasibility Proposals to Gettier problem? Hekmat Va Falsafet (Wisdom and Philosophy), 7(4).

Dancy, J. (1981). Introduction to Contemporary Epistemology. London: Macmillian Press Ltd.
Demin, T. S. (2019). Gettier Problem. Epistemology \& Philosophy of Science, 56(3), 58-75. https://doi.org/10.5840/eps2019 56349

Depestre, R. (2007). Sartre in his fraternity. In Diogenes (Vol. 54, Issue 4, pp. 41-45). https://doi.org/10.1177/0392192 107086527

Edmund Gettier, "Is Justified True Belief Knowledge?" Analysis 236,1963

Plato. (1999). "Meno" The Great Books of the Western World Mortimer J. Adler (ed), Chicago: Enyclopedia Britannica Inc.

Pratt, J. (2015). On the threshold of rhetoric: Gorgias' Encomium of Helen. Classical Antiquity, 34(1), 163-182. https://doi.org/10.1525/CA.2015. 34.1.163

Rodgers, N., \& Thompson, M. (2011). Existentialism Made Easy, London: Hodder Education.

Schick, T \& Vaugham L, (1999). Doing philosophy: An Introduction through Thought Experiments, New York: Mcgraw Hill.

Stumph, S. E. (2002). Element of photography. An introduction, $4^{\text {th }}$ Edition, New York: McGrew Hill. 